Article

\title{
Environmental Citizenship Education through the Doñana, Biodiversity and Culture Program
}

\author{
M Ángeles de las Heras Pérez *D, Bartolomé Vázquez Bernal (D), Rocío Jiménez Palacios and Roque Jiménez Pérez \\ Integrated Didactics Department, Faculty of Education, Psychology and CC. Sport, University of Huelva, \\ 21071 Huelva, Spain; bartolome.vazquez@ddcc.uhu.es (B.V.B.); rocio.jimenez@ddcc.uhu.es (R.J.P.); \\ rjimenez@ddcc.uhu.es (R.J.P.) \\ * Correspondence: angeles.delasheras@ddcc.uhu.es; Tel.: +34-6-354-08984
}

Citation: de las Heras Pérez, MÁ.; Vázquez Bernal, B.; Jiménez Palacios, R.; Jiménez Pérez, R. Environmental Citizenship Education through the Doñana, Biodiversity and Culture Program. Sustainability 2021, 13, 2809 https://doi.org/10.3390/su13052809

Academic Editors: Andreas

Ch. Hadjichambis, Pedro Guilherme Rocha dos Reis,

Demetra Paraskeva-Hadjichambi, Marta Romero Ariza, Jelle Boeve-de

Pauw, Niklas Gericke, Marie

Christine P. J. Knippels and

Andri Christodoulou

Received: 2 February 2021

Accepted: 26 February 2021

Published: 5 March 2021

Publisher's Note: MDPI stays neutral with regard to jurisdictional claims in published maps and institutional affiliations.

Copyright: (c) 2021 by the authors. Licensee MDPI, Basel, Switzerland. This article is an open access article distributed under the terms and conditions of the Creative Commons Attribution (CC BY) license (https:/ / creativecommons.org/licenses/by/ $4.0 /)$.

\begin{abstract}
While the need to educate for the formation of environmentally committed citizens is something that has always been recognized, currently however it has become an obligation. The present study analyzes the Doñana, Biodiversity and Culture Program from the perspective of its participants. The program is part of the action being carried out with schools intending to teach environmental citizenry using the context of protected natural spaces, in this specific case, the Doñana National Park. The Park's managers and public guides were interviewed, and observation records of the process were collected. These were later analyzed by means of a category table elaborated within the project Patrimonial Education for Citizens' Territorial and Emotional Intelligence, of which this study is a part. The consistency of the informants was verified, as also was the practice observed, showing the importance of the socio-identity framework, of critical thinking, and of socio-affective relationships with the territory.
\end{abstract}

Keywords: environmental citizenship; Doñana; emotional intelligence; territorial intelligence; identity

\section{Introduction}

Spain is the country with the third highest volume of assets declared as World Heritage Sites by the UNESCO, among which is the Doñana National Park that was included 50 years ago [1]. In all of these areas, there is a wide range of heritage which needs to be admired and committed to so as to intervene and transform society in favor of that heritage [2]. With regard to natural heritage in particular, this objective can be achieved through the development of environmental citizenship, which [3] defines as a citizenry with proenvironmental behavior in every aspect of their lives, and which considers equity in the distribution of goods and participation in the creation of a sustainability policy. As noted by [4], it is a matter of citizens who participate actively in the path towards sustainability.

Based on the definitions of environmental citizen given by the previous authors, we can affirm that the generation of citizens committed to the environment is basic and of great importance at the time of environmental crisis that we are experiencing [4]. Everything suggests that an environmentally literate society [5] will prevent or provide the means to recover the environment and prevent its further deterioration.

Ref. [6] describes that the best way to get environmental citizens is by involving them in solving environmental problems and not sitting in a classroom listening: "the idea of environmental citizenship can be made real by getting pupils involved in a project that involves part of the school or even all of it" [6] (p. 285). All programs carried out through both formal and non-formal education will be welcomed to achieve more conscientious citizens and, ultimately, a reduction in the loss and degradation of the environment. As [7] warns, environmental citizenship could develop a more sustainable society and world with the transformation of values, beliefs, attitudes, and behavior.

To this, it must be said that more and more schools are betting on developing environmental training programs for their students, designed in the line of achieving an 
improvement in their conceptualization and their attitude towards the environment. The literature review reveals the increase in programs in both formal and non-formal education, summarizing their results in the generation of citizens more committed to the environment.

Education is in charge of this task, analyzing and developing didactic proposals through research, in formal and non-formal, transdisciplinary and socio-critical contexts, working from socio-scientific controversies.This promotes the construction of values of identity, intercultural respect, and social change, and leads to the formation of citizens who are socioculturally committed and critical [8,9], but also who have a broad environmental culture [10] developed on the basis of acquiring environmental knowledge from real life and personal experiences [11].

The present study is framed within a project called "Heritage Education for the territorial and emotional intelligence of citizens. Analysis of good practices, design and intervention in compulsory education" (EDU2015-67953), to which has been assigned the DESYM (Didactics of Experimental, Social and Mathematics) research group of the University of Huelva, called EPITEC (Heritage Education for Territorial and Emotional Intelligence of Citizens). This project has been contributing knowledge of the didactic proposals that connect schools with heritage institutions since 2017.

The intention of the study was to gather knowledge about the Doñana, Biodiversity and Culture Program as a path in environmental education for citizenship, working from the Park's Heritage Center with local schoolchildren so as to generate a territorial bond, developing territorial and emotional intelligence.

\section{Theoretical Foundation}

\subsection{The Need for Environmental Citizenship}

Today, both globally and locally, environmental problems constitute one of the main issues facing humanity. The dominant economic development model is responsible for the great imbalance that affects both the environment and part of our own society. The consequences in terms of the deterioration of nature are becoming ever more obvious, and are sending a warning alarm to change direction, and even the necessity to retrocede as expressed in the theory of contraction [12,13]. It is clear that this situation needs to be known by every citizen to achieve a more responsible treatment and a citizen profile that is more consistent with today's situation.

If something is clear at present, it is the need to generate environmental awareness in citizens to achieve a change in the relationships, humans have with their environment and their active commitment towards this goal [7]. But it must not be forgotten that we are today more than ever living in a global world, and therefore that, as expressed by [14], the formation of global citizenship is essential if we wish to advance along the path of sustainability.

Education is key to achieving environmental awareness and sensitization [15], to achieving a profile of a citizen who is environmentally congruent with today's reality, who is not only aware of their rights but also of their environmental duties. For this, it is important to achieve sustainability of the curriculum, i.e., to accommodate relevant socioecological problems and to use academic knowledge at the service of these problems [16]. But in addition, it is important to apply environmental education programs that promote knowledge and skills to preserve the environment as indicated by [17], as may be the case of the program that is presented, Doñana, Biodiversidad y Cultura. Many programs like this have been carried out, raising awareness of the environment and mitigating environmental deterioration $[18,19]$. But in addition, some of them incorporate cutting-edge technology, using mobile devices and their applications, such as QR codes, both for environmental education purposes, as well as education for sustainable development [20].

\subsection{Natural Heritage and Territorial Intelligence}

In recent years, heritage seems to be gaining ever more importance within academic and institutional spheres. There have been numerous research studies dedicated to Heritage 
Education and its connections with formal, non-formal, and informal areas [21,22], with a significant increase over the last decade [23]. Research in this area has been a motor driving the development of our country, generating thought, proposals, and advances to give it a role in accordance with the relevance of its assets [24]. Although there is still an important traditionalist weight in how it is treated, there is a movement towards proposals that posit a more open, flexible, interactive, and dynamic heritage communication [5]. There is also the conceptualization of holistic heritage given by [25] and adapted for other related research.

Regarding education and heritage divulgation, according to [26], and applied to the field that concerns us here, transmissive proposals in which information communication comes first must be put aside, and participatory and interactive proposals must be opted for. In these, heritage can be understood as an active part of society, fostering social values related to respect and cultural identity, as well as awakening emotions and allowing the public to develop as persons and as critical citizens [27].

In parallel with the above in the sense of heritage education, ref. [28] establishes that non-formal environmental education has made it possible to mobilize skills, attitudes, and feelings that give meaning to the behaviors that are adopted regarding the environment. This same author defends education in action, and states that [28] (p. 159) "There will never be enough emphasis on the importance of this relationship between what is learnt mentally and what is put into execution through the hands, body, conscious decisions, and participation". In this case, non-formal education meets a requirement that cannot be met by the classroom, although what really needs to be sought is the feedback or active symbiosis between the classroom and nature, relationships that are analyzed in the work of [21,29-32].

The term Territorial Intelligence is used to try to bring together the two objectivesheritage education from a landscape perspective, and environmental education from a sustainability perspective. In particular, because of its relationship with heritage, the term might be appropriate for the aspects that concern us here. It was proposed so as to give a scientific dimension to the "Catalyse" experience [33] which consists of a method and observational tools for the territorial actors who wish to elaborate, argue for, encourage, and assess sustainable development projects.

The concept of Territorial Intelligence defined in [33] revolves around the following three fundamentals: sustainable development as an alternative to development economics; the importance of territories for community action; and information and communication sciences and technologies as a vector of development and a tool for the construction of a collective intelligence.

In sum, this concept aspires to promoting reflection on the economic, social, environmental, and cultural challenges of globalization in the territorial sphere. It therefore cannot be understood as a discipline, but rather as a scientific approach to constructing pluridisciplinary knowledge through the dissemination of multiple knowledge [34].

\subsection{Natural Heritage, Identity, and Emotions}

Environmental, social, and cultural challenges can be associated with territorial identity and the emotions that underlie its knowledge. Ref. [35] couples the existence of two minds - one that thinks and the other that feels.

It is evident that the conflict between emotion and reason has kept the role of emotions on the sidelines. However, references to them date back more than two centuries according to some exhaustive reviews such as those [36] and [37], or Darwin's references to their influence on his theory of the evolution of the species. They are currently taking on another consideration due to the new contributions from neuroscience [38] and the origins of emotions in the brain (Damasio, 2005) which are offering neurobiological support to the relationship between emotions, actions, feelings, and reasoning. Today, emotions constitute a spearhead linked to teaching and learning. This is sustained because, from a broad perspective, together with various other authors $[35,39,40]$, we can subscribe to the opinion 
that behind an action there is always an emotion. We would focus this on the relationship of emotions with education, and specifically with symbolic identity in natural heritage.

The identity we refer to converges into a way of life that signifies part of culture. Thus, this study will consider the Doñana National Park as a symbolic-identity natural heritage. As expressed by [41], the natural and cultural heritage that coincides with a landscape or territorial heritage is an asset in itself which needs to be preserved and improved as a quality. With all certainty, the environment itself arouses emotions in humans as a consequence of their being or having been part of it. What really extends to other social groups or has a greater social breadth is the set of symbols that the environment contains and which are what really produce feelings aroused by the emotions. According to [42], individuals or groups are identified by referring to the properties that make them different from others in a particular frame of reference. But when it comes to the identity which refers to the territory, ref. [41] argues, quoting [43] who includes it as one of his seven types of knowledge necessary for future education (the teaching of terrestrial identity), that this means overcoming barriers through attitudes of solidarity and responsibility with the environment as if it were one's own homeland. In this case, one rediscovers the sense of belonging and of associated identity. However, it is difficult to find in the literature this sense of belonging linked to territorial or environmental feelings promoted by emotions and that entail attitudes of responsibility towards their conservation and improvement.

Ultimately, if emotions define actions, the latter will constitute the most important aspect in terms of education [44]. That is why authors such as [40] argue for early training in emotional education.

\section{Materials and Methods}

\subsection{Characterization of and Approach to the Research Problem}

The present research study was qualitative since it describes key incidents in descriptive and functionally relevant terms, contextualizing them in the social environment in which they occur [45]. Its approach is descriptive-interpretive, the aim being to document in maximal detail how the technical team in charge of disseminating knowledge of the natural heritage of the Doñana district in schools through an educational program that they themselves developed so as to form a bond between the pupils and the territory, i.e., to achieve environmental citizenship. In this way, we plan to determine:

- How does the Doñana, Biodiversity and Culture Program plan the education of environmental citizenship?

- More specifically, we propose to determine:

- What were the thoughts of the Doñana National Park technical team, based on the instrument developed by the EPITEC project, regarding the pupils achieving emotional and territorial intelligence and, ultimately, their environmentalization as citizens?

- What type of activities are proposed during the development of the Educational Program, and for what purposes?

\subsection{Participants}

The cases selected for study are incidental in nature and consist of three parts. On the one hand, there are two managers of public use of the Doñana National Park. They belong to the Environmental Education program for the educational community. Then, on the other, there is one of the guides responsible to the visits to Doñana with schoolchildren. The third pillar of the sample is a school that belongs to the Doñana district, selected after being considered by the technical team as a center with good practices.

Regarding the profile and professional experience of the public use managers, we would note that both had received training in environmental education, with one having a Master's Degree in Environmental Education. Likewise, it is important to note that both are immersed in the world of education, one being a primary education teacher. Regarding the educational background of the guide at the Doñana interpretation center, it should be noted 
that he has a degree in Agricultural Technical Engineering as well as having completed numerous training courses taken while working as a guide over the last 30 years.

The school selected for the observation process required by the study was CEIP Marismas de Hinojos (Hinojos, Huelva). The sample was limited to a class of 6th year of Primary. It is important to highlight the geographical location of the school which is very close to the National Park, belonging to what is denoted the Doñana Environment District.

\subsection{Description of the Doñana, Biodiversity and Culture Program}

The Doñana, Biodiversity and Culture Program is immersed in the line of environmental education intervention within the Aldea Program's Espacios Naturales de Andalucia. It is targeted at pupils of their 6th year of Primary Education. It consists in carrying out a didactic itinerary through an emblematic site of the National Park. Specifically, it comprises two parts:

- Visit of the Park staff to the school, specifically to the 6th of Primary classes. Here, they present the Doñana Natural Area and the activity that will take place.

- Visit to the Doñana Natural Area with the pupils. For four hours, a tour is made of the area, during which, through the different activities (Table 1), the content of natural (fauna, flora, ecosystems) and cultural (history, lifestyles, traditions) heritage and the objectives of the project are worked on, i.e., to create a bond of identity with the territory so as to achieve the education of environmental citizenship.

Table 1. Development of the itinerary "El Rocío from La Vera" as part of the Doñana, Biodiversity and Culture Program.

\begin{tabular}{|c|c|c|}
\hline \multicolumn{3}{|c|}{ Category I. Why Natural Heritage Is Taught } \\
\hline Activity & Objective & Development \\
\hline $\begin{array}{l}\text { 1. Presentation of } \\
\text { the Territory }\end{array}$ & $\begin{array}{l}\text { Locate today's reality of the Territory } \\
\text { of Doñana }\end{array}$ & $\begin{array}{l}\text { Before entering the Park, but in front of the marsh that belongs to it, the guide } \\
\text { briefly introduces the pupils to what the territory is, the municipalities that form } \\
\text { it, its uses, its fragmentation, and the consequences of all this. }\end{array}$ \\
\hline $\begin{array}{l}\text { 2. The objective of the } \\
\text { outing and the } \\
\text { Manecorro route }\end{array}$ & $\begin{array}{l}\text { Raise awareness about the privilege of } \\
\text { belonging to that territory and } \\
\text { generate an identity bonded with it }\end{array}$ & $\begin{array}{l}\text { Once located at the gate that gives access to the Park, the guide explains to the } \\
\text { pupils what the outing will consist of, and makes them aware that they are } \\
\text { going to visit an area that is very restricted but that they are there because they } \\
\text { themselves belong to the territory. }\end{array}$ \\
\hline $\begin{array}{l}\text { 3. Description of } \\
\text { animal tracks }\end{array}$ & $\begin{array}{l}\text { Know and give value to the diversity } \\
\text { of fauna that exist in the territory }\end{array}$ & $\begin{array}{l}\text { The guide takes advantage of the tracks that are on the path to work on } \\
\text { their interpretation. }\end{array}$ \\
\hline $\begin{array}{l}\text { 4. Dealing with } \\
\text { forest fires }\end{array}$ & $\begin{array}{l}\text { Emphasize that people who are from } \\
\text { the territory and who live in it, take } \\
\text { care of it, thus generating an } \\
\text { environmental awareness }\end{array}$ & $\begin{array}{l}\text { Under a fire control tower, the guide works with the pupils about the problems } \\
\text { caused by fires in the territory and how there are people dedicated to this issue. }\end{array}$ \\
\hline $\begin{array}{l}\text { 5. Skeleton of a } \\
\text { dead animal }\end{array}$ & $\begin{array}{l}\text { Work on the traditional use of the } \\
\text { territory by humans and the } \\
\text { possibility of living off the territory in } \\
\text { a sustainable way }\end{array}$ & $\begin{array}{l}\text { Along the path taking advantage of a landmark that appears in the territory, } \\
\text { such as the corpse of an animal. The guide asks different questions about the } \\
\text { type of animal that it could be, about how it might have died ... From there the } \\
\text { uses that are currently made of the territory and by whom they are made, such } \\
\text { as breeding mares, traditional fishing, charcoal, sustainable housing. }\end{array}$ \\
\hline $\begin{array}{l}\text { 6. Observation and } \\
\text { valuing the Territory }\end{array}$ & $\begin{array}{l}\text { Generate the pupils' bond with the } \\
\text { territory and create } \\
\text { environmental awareness }\end{array}$ & $\begin{array}{l}\text { Once, when they are at an emblematic point of the outing, the guide makes } \\
\text { them observe certain outstanding points and aspects of nature that are difficult } \\
\text { to observe in other places, and makes them aware of the importance of that } \\
\text { place and of the importance and exclusivity of their belonging to that territory. }\end{array}$ \\
\hline 7. Marked trees & $\begin{array}{l}\text { Giving value to the vegetation in the } \\
\text { area and working on the traditional } \\
\text { uses and the human/nature balance }\end{array}$ & $\begin{array}{l}\text { This activity takes place in front of a cork oak that is marked with a number, } \\
\text { and, due to the amazement of the children about this fact, the guide takes } \\
\text { advantage of it to work on the vegetation of the territory, its emblematic species, } \\
\text { and the use that humans have made of them throughout history. }\end{array}$ \\
\hline 8. Rest and breakfast & $\begin{array}{l}\text { Rest and refreshment. Generating } \\
\text { environmental awareness and a } \\
\text { respectful use of the territory }\end{array}$ & $\begin{array}{l}\text { While the pupils rest and recover strength, the teachers take the opportunity to } \\
\text { refer to healthy eating and selective trash and garbage collection, which is also } \\
\text { carried out. }\end{array}$ \\
\hline 9. Final activity & $\begin{array}{l}\text { Recapitulation of what has been } \\
\text { observed during the outing }\end{array}$ & $\begin{array}{l}\text { The pupils, in small groups, are asked to make a RAP that collects together what } \\
\text { they experienced during the outing. In the end, the best will be voted for and } \\
\text { will become the anthem of the outing. }\end{array}$ \\
\hline
\end{tabular}




\subsection{Instruments of Data Collection and Analysis}

In order to collect the necessary information to fulfill the proposed objectives, we chose two types of instruments to use. On the one hand, we used the interview both with the Doñana National Park public use managers and with the guide in order to know how they approach and implement the program. The interviews were open. Very specific topics were addressed, such as information about the program carried out (work dynamics, design, participants ... ), how the pupils perceive Doñana and whether they recognize its importance, whether the schools do a follow-up after finishing the outing (to determine whether it is carried out with educational interest). Other issues arose spontaneously during the course of the two interviews. These were recorded on audio and later transcribed to be analyzed. On the other hand, we used an observation record to address the school pupils' description of the outing, and thus be able to characterize the activities they carried out. To this end, we accompanied these 6th of Primary Education pupils to the Donana National Park. During the course of this outing, we limited ourselves to using non-participant direct observation, recording the data in a field diary. Likewise, videographic recorders were used to take photographs and videos.

To analyze the information collected during the research process, we used a category system (Table 2). This instrument was adapted from the one used in the EPITEC project (of our own research group), which initially presents five categories. On this occasion, we analyzed three, which are divided into various subcategories, indicators, and descriptors to facilitate the assignment and interpretation of the information units in the analysis process. The category system is generally organized as a development hypothesis, composed of various levels of complexity organized from the simplest to the most complex, except in the case of Subcategory 1 (Towards which approaches the proposal is oriented).

Table 2. Categories, subcategories, indicators, and descriptors used in the information analysis.

\begin{tabular}{|c|c|c|}
\hline \multicolumn{3}{|c|}{ Category I. Why Is Natural Heritage Taught? } \\
\hline Subcategories & Indicators & Descriptors \\
\hline \multirow{5}{*}{$\begin{array}{l}\text { 1. Towards what } \\
\text { approaches is the } \\
\text { proposal oriented? }\end{array}$} & Emotional intelligence & $\begin{array}{l}\text { The individual's ability to become aware of their emotions, understand the feelings } \\
\text { of others, and develop an empathic and social attitude. }\end{array}$ \\
\hline & Civic education & $\begin{array}{l}\text { Educate politically and morally active people, who are aware of their rights and } \\
\text { obligations, committed to defending democracy and human rights, who are } \\
\text { sensitive and solidary with the circumstances of others and with the environment in } \\
\text { which they live. }\end{array}$ \\
\hline & Environmental education & $\begin{array}{l}\text { Educate people to be aware of the deterioration of the environment and the } \\
\text { overexploitation of natural resources, committed to the defence and protection of } \\
\text { nature and sustainable development. }\end{array}$ \\
\hline & Territorial intelligence & $\begin{array}{l}\text { Ability of people to combine economic, social, environmental, and cultural objectives } \\
\text { within the framework of a sustainable development model in a given territory. }\end{array}$ \\
\hline & Scientific and cultural literacy & $\begin{array}{l}\text { Not only provide people with a scientific language, but also teach them to demystify } \\
\text { and decode the beliefs concerning science and scientists, to ignore their apparent } \\
\text { neutrality, to enter into epistemological questions and the terrible inequalities } \\
\text { caused by the misuse of science and its socio-political constraints. }\end{array}$ \\
\hline \multirow{4}{*}{$\begin{array}{l}\text { 2. What is the purpose of } \\
\text { the educational process? }\end{array}$} & Academic & $\begin{array}{l}\text { Knowledge of facts and information of a cultural nature, illustrated and/or focused } \\
\text { on anecdotal aspects. }\end{array}$ \\
\hline & Propaganda & Valuation of heritage assets for political and/or economic interests. \\
\hline & Practical-conservationist & $\begin{array}{l}\text { Heritage values in daily life (economic, identity, etc.) and fostering } \\
\text { their conservation. }\end{array}$ \\
\hline & Sociocritical & $\begin{array}{l}\text { Educating critical citizens committed to defending sustainable development in the } \\
\text { field of heritage. }\end{array}$ \\
\hline \multicolumn{3}{|c|}{ Category II. What Relationships Are Established Between Emotional Intelligence and Natural Heritage? } \\
\hline \multirow{3}{*}{$\begin{array}{l}\text { 3. What dimensions of } \\
\text { learning are established? }\end{array}$} & Cognitive & Focused on content. \\
\hline & Emotional & Focused on motivations and incentives. \\
\hline & Social & Focused on interactions. \\
\hline
\end{tabular}


Table 2. Cont.

\begin{tabular}{|c|c|c|}
\hline \multirow{3}{*}{$\begin{array}{l}\text { 4. What skills are } \\
\text { developed through } \\
\text { emotional intelligence? }\end{array}$} & Intrapersonal intelligence & $\begin{array}{l}\text { Emotional self-awareness, assertiveness, self-respect, self-actualization and } \\
\text { independence, stress, and mood management. }\end{array}$ \\
\hline & Interpersonal intelligence & Empathy, interpersonal relationship, and social responsibility. \\
\hline & Adaptation to the environment & Problem solving, reality testing, and flexibility. \\
\hline \multirow{4}{*}{$\begin{array}{l}\text { 5. What are the } \\
\text { constitutive elements of } \\
\text { identity/heritage? }\end{array}$} & Affective-emotional & $\begin{array}{l}\text { Social relationships (family, friends, associates) and patrimonial references } \\
\text { associated with them (festive elements, gastronomy, daily life tools). }\end{array}$ \\
\hline & Territorial & $\begin{array}{l}\text { Natural, spatial, and architectural elements and landscapes associated with } \\
\text { socio-historical events. }\end{array}$ \\
\hline & Socio-political conventions & $\begin{array}{l}\text { Conventional socio-political elements (flag, anthem, coats of arms) and all the } \\
\text { patrimonial references typified in the legislation. }\end{array}$ \\
\hline & Identity multiplicity & $\begin{array}{l}\text { Integration of all the previous elements and giving value and respect to the } \\
\text { diversity of identities. }\end{array}$ \\
\hline \multicolumn{3}{|c|}{ Category III. What Relationships Are Established between Territorial Intelligence and Natural Heritage? } \\
\hline \multirow{3}{*}{$\begin{array}{l}\text { 6. What view of the } \\
\text { landscape is worked on? }\end{array}$} & Musealized & Perception of the landscape as a fixed, immovable, and unalterable photo. \\
\hline & Sustainable & $\begin{array}{l}\text { Perception of human interactions with nature and the problems associated } \\
\text { with this. }\end{array}$ \\
\hline & Cultural & $\begin{array}{l}\text { Valuing the identity and perceptions of the individual in relation to nature. } \\
\text { Understanding nature as part of the culture of a society. }\end{array}$ \\
\hline \multirow{3}{*}{$\begin{array}{l}\text { 7. What view of } \\
\text { citizenship is worked on? }\end{array}$} & Individual citizenship & $\begin{array}{l}\text { Personally, responsible citizenship, with a sense of belonging to a community. } \\
\text { Recognition of the symbolic and identity value of those heritage elements } \\
\text { exclusively that are close-by and directly related to the individual through their } \\
\text { personal experience. }\end{array}$ \\
\hline & Social citizenship & $\begin{array}{l}\text { Active member of organizations and/or initiatives to improve their community. } \\
\text { Community identity. Recognition of the symbolic and identity value of heritage } \\
\text { elements related to one's own culture. }\end{array}$ \\
\hline & Global citizenship & $\begin{array}{l}\text { Citizens of the world, who respect and value cultural diversity (intercultural } \\
\text { citizenship). Commitment to building a juster society. Recognition of the symbolic } \\
\text { and identity value of heritage elements external to one's own culture. }\end{array}$ \\
\hline \multirow{3}{*}{$\begin{array}{l}\text { 8. What view of the } \\
\text { environment is } \\
\text { worked on? }\end{array}$} & Protectionist-conservationist & No involvement in the procedures. \\
\hline & Activist & Without foundation. \\
\hline & Sustainable development & Rationale + involvement. \\
\hline \multirow{4}{*}{$\begin{array}{l}\text { 9. What connection with } \\
\text { the environment } \\
\text { is addressed? }\end{array}$} & Without connection & No connections between heritage and environment are established. \\
\hline & Institutional & Connecting links are established with the surrounding heritage institutions. \\
\hline & Territorial & $\begin{array}{l}\text { Connections are established between heritage and the surrounding environment } \\
\text { (neighbourhood, village, autonomous community, for example). }\end{array}$ \\
\hline & Inter-territorial & $\begin{array}{l}\text { Connections are established between heritage and other territorial areas (other } \\
\text { autonomous communities and regions). }\end{array}$ \\
\hline
\end{tabular}

\section{Results}

\subsection{Analysis of the Managers' Interviews}

The results will be presented structured according to the categories that guided the research, highlighting the parallels and divergences, if any, between the thinking of the public-use managers (MAN) and of the park guide (GUI), supported by their occurrences in the activities carried out.

\subsubsection{Category I. Why Is Natural Heritage Taught?}

In this first category and, considering specifically Subcategory 1 which refers to the foci of the proposal, as indicated above, the indicators do not follow any order of progression, so that they will each be analyzed. The first indicator refers to creating in the pupils emotions of affect towards the territory, by taking them during the outing to a protected place and transmitting to them that they are in that special place because they themselves belong to that environment: 
"... 6th Primary Education, which for us is key in the program as it is the last year before Secondary Education. We therefore want it to be the moment when they have a unique experience and feel super special (privileged) for being children from the district." [MAN]

[MAN]

"... because they are the ones most involved in the matter, as they are specifically within the Doñana biosphere."

[GUI]

In addition, the proposal is aimed at achieving the pupils' Citizen and Environmental Education, i.e., environmental citizenship, educating persons who are critical with social issues and with the territory, knowing, valuing, and conserving the biodiversity that is present in it:

"... we treat them differently so that, in the future, they will help us conserve this."

\section{[MAN]}

"Of course, they really don't know what their role is, what their mission in Doñana is, and we have to point it out for them. The first thing we do is take a map and show them their location so that they start to become aware. Afterwards, all this is reinforced with activities, and, in the end, when they are entrepreneurs and adults, they will see Doñana in a different way."

\section{[GUI]}

Environmental Education in Doñana has been a milestone since its creation:

"... there is another small facet that we have, which is environmental education. It is very very important. We have been doing environmental education for 40 years. It is one of the first environmental education programs in the world ..."

\section{[GUI]}

Working on the territory in this overall and holistic way, socially and environmentally, it is possible to improve the pupils' Territorial Intelligence and Eco-literacy:

"... we try not only to see the natural value but also elements of the uses and customs, as well as the history of Doñana."

\section{[MAN]}

"... we talk about traditional uses, charcoal, pine cones, we comment on the economic part, what is done with the pine nuts (piñones) ..."

[GUI]

As is notable from the analysis of these information units, the program highlights all these ideas which coincide with the basis of the project as part of which it is being analyzed, and with the principles for the achievement of environmental citizenship.

With regard to Subcategory 2, the purpose of the educational process, we can see that there is a duality within the program. On the one hand, there is the intention to give value to the natural heritage and foster its conservation:

"Through this, for example, we contacted women's associations that value gastronomy, traditional festivals, etc. This was an important and costly task, although of great interest because the pupils get to know the territories, their traditions and history since the starting point is that Doñana is us who live in Doñana."

[MAN]

"We are going to show the value of Doñana and make it known to them. We start with them. Children are the most sensitive population."

\section{[GUI]}

On the other hand, the aim is to educate future critical and committed citizens who know and are able to value the environment in which they live so as to preserve it: 
"It is they (referring to the children) who, in the future, will have to continue this task of conservation. In fact, Doñana does this. As I say to the children, we want you to know this because, to want to conserve it, first you have to know it."

[MAN]

"... for us, it is essential to work with the school population, to consider that the future of a village, a region, a community... lies with the children. Therefore, it is very important. ... For the population to respect and preserve and know an environment, the children have to respect and know it. They have to enjoy it. This is fundamental."

[GUI]

In summary, with regard to Subcategory 2, the program aims to give value to the territory and to achieve critical citizens who know how to take care of it, thus generating environmental citizenship.

4.1.2. Category II. What Relationships Are Established between Emotional Intelligence and Natural Heritage?

To analyze the relationships that arise between emotional intelligence and heritage, three subcategories are established. The first refers to the dimensions of the learning that are established, and, due to what is observed, this can be considered a social vision, i.e., a vision where the cognitive is mixed with the emotional, and their interactions:

(speaking about activities that were carried out in the surrounding villages) " ... these are very beautiful experiences and every time we pass by we remember the image each village has of Doñana..."

[MAN]

"... we try the same with the kids, for them to see themselves as part of Doñana and extrapolate this to their village, to say, hey, this is Doñana but that there are areas like these in your village too..."

[GUI]

The second subcategory refers to the skills developed through emotional intelligence, both intra- and inter-personally. At the intrapersonal level, an attempt is made to develop a link with the territory by empowering the pupils to belong to it:

"... they are children who are closely linked to the territory ... they are children who know the world of birds, capable of recognizing feathers, fed up with hearing the geese above their house..."

[MAN]

"... it is very important for us to work with the school population, to consider that the future of a village, a region, a community ... lies in the children ..."

[GUI]

Likewise, at the interpersonal level, they work on empathy with the people who use and work and live in the territory as part of it, and their need for it to be conserved so that it survives and can be used by future societies, thus generating an environmental awareness:

"... it was interesting to know that Doñana is not only the National or Natural Park, but that Doñana is us who live in Doñana and it is what unites us ..."

[MAN]

"... because they are our children, and if we do not educate them, when they are older, when they are the Mayors, when they are influential people in their villages, they will not look to take care of Doñana ... we are going to give value to Doñana and we are going to let them know about it ..."

[GUI] 
The last subcategory has to do with the constitutive elements of identity and heritage. This is developed from putting an emphasis on the area's heritage elements-natural, ethnographic, and cultural-and showing the pupils that these elements belong to that territory and are not found outside it, thus becoming symbols that identity the inhabitants of the area and, therefore, they themselves. For them, the Virgen del Rocío belongs to them. Therefore, one way to create identity with the territory is to emphasize that it is necessary to take care of that territory so that nothing happens to the Virgin. Another important identity marker is the Iberian lynx. It is like their banner:

"... the particularity of these children is that they live so close to Doñana ... that they do not consider it anything extraordinary or special ... they are special because they live where the Virgin lives."

[MAN]

"The outsider and the insider, everyone wants to see the lynx ... fortunately, almost all the children belonging to the environment of Doñana have seen it."

[GUI]

4.1.3. Category III. What Relationships Are Established between Territorial Intelligence and Natural Heritage?

To address the relationships that are established between territorial intelligence and heritage, we start with four subcategories that refer to the treatment of the landscape, citizenship, environment, and connection with the territory. If we first analyze these four subcategories in an overall way, we can observe that the tendency is to work with the territory not only naturally, but also by joining the natural landscape and humans together as a result of the identity culture of that territory. It is therefore developed from the perspective of Territorial Intelligence.

If we stop to consider the perspective towards the landscape, this is centered between sustainability and culture, i.e., it identifies the human interactions with nature and the problems that they entail, but it also takes into account a view of nature as part of the culture of a society. Thus, an attempt is made to create environmental awareness where, through knowledge of traditional uses, the pupils learn that it is permitted to live off the environment, but that it should be done in a sustainable way:

"... in 6th, we have an itinerary called "Doñana, El Rocío from La Vera" where we take the children along a route that is not open to the public, a route that we designed and in which we try not only to see the natural value but also elements of the uses and customs, as well as the history of Doñana."

[MAN]

(referring to the Manecorro activity) "The objective is to spend three or four hours with them, integrating them in nature, integrating them in the country, making them be just one more, and that the country is not an enemy."

[GUI]

The concept of citizenship is not worked on from the reference level, i.e., from a global citizenship level, but rather as a concept of social citizenship, recognizing the symbolic and identity value of heritage elements related to their own culture, because that is precisely the objective set in the program being analyzed:

"... a program belonging only to the district of Donana (heritage elements close-by and directly related to the individual). Since the 1980s, there has been a group called Doñana Environment. This group of educational participations is formed by representatives of 14 municipalities in the Doñana district with their municipal representatives ... We created a network among the 14 municipalities and ourselves to bring environmental education to the municipalities."

[MAN] 
"For the population to respect and preserve and know an environment, the children have to respect it and know it, they have to enjoy it, this is fundamental."

[GUI]

However, in some cases, they allude to the need to extrapolate what the pupils have learnt in this territory to other external ones.

"We focus on Doñana because we are in Doñana. What we are trying to do is give them some guidelines... This is Doñana but it can be extrapolated to other towns and villages, their pine forests, their lagoons ..."

[GUI]

With regard to Subcategory 8 or the vision of the environment being worked on, we can state that there is a double view. On the one hand, they present a protectionist/conservationist interest in the sense of achieving the durability of the natural space, but without forgetting their view from a sustainable development perspective:

"Yes, they are also the ones who in the future are going to have to continue this task of conservation ... as I tell the children, we want you to know this in order for you to want to conserve it ..."

[MAN]

"Therefore, your interest is that this area continues to be as it is? Of course, to preserve it ... " [GUI]

"At present it is not like before. Before, Doñana was a kind of enemy, you couldn't build buildings, plant strawberries,... Thus it was an enemy. Currently everything is Doñana, Doñana feeds many people, now it really is a friend."

\section{[GUI]}

Finally, the connection made with the environment is a territorial connection that links the natural heritage, its uses and customs, emphasizing the need for sustainable use. In this sense, they continue to express the need to create environmental awareness so as to generate future environmental citizenship:

"Yes, we talk about traditional uses, charcoal, pine cones, we talk about the economic part, what is done with the pine nuts (piñones). We comment that this is a very good pine nut, and that the Doñana pine nut is today eaten in Saudi Arabia. We also ask them how they are currently heated at home, and what would happen if the power goes out, we explain that before there was a thing called charcoal."

[GUI]

\subsection{Analysis of Activities}

If we stop now to consider the analysis of the activities carried out during the outing (Table 1), broadly speaking, these are based on achieving three main objectives aimed at forming future environmental citizenship: showing the value of the territory of Doñana through its fauna and flora, highlighting that since time immemorial it has been a territory used by humans in a sustainable way, and creating a bond between the pupils and the territory by way of generating an identity between them.

Thus, the intention with Activities 3 and 7 is to value the territory or, which is the same, to show the value of the territory through its fauna and flora, as well as to value the human/nature balance by working on the sustainability of the traditional uses of the territory.

In Activity 4, with a fire tower as a landmark, this issue is worked on with the pupils. Advantage is taken of the intervention of a child who mentions that his father works in this sector so as to stress the value the people of Doñana give to the territory. In this way, environmental awareness is being created in the pupils as well as the respectful use of the territory, in sum, educating for potential environmental citizenship. 
Activity 5 also has the aim of working on the traditional uses of the territory, and promotes the possibility of living in the territory in a sustainable way.

During Activities 2 and 6, the idea is reinforced of the privilege they have of enjoying the territory, together with the reason that they are there because they are people from that territory. This generates bonds of emotional identity and environmental awareness.

By way of triangulation, when we contrast the objectives that are intended to be reached through carrying out the activities with the categories used to analyze how the program is set out through the thinking of the informants, we see that there is a great confluence. Thus, the first category, which alluded to why is Natural Heritage taught, has as its response, that it is to achieve the pupils' Citizenship and Environmental Education through showing the value of Doñana, of its natural elements, and of its traditional uses, worked on in Activities 3 and 7. Ultimately, how the program is set out and the activities are both committed to achieving environmental citizenship.

With regard to the category that deals with the relationship between Territorial Intelligence and Natural Heritage, knowledge of the territory is addressed not only from a natural perspective but also from one of sustainable use of the territory by those who live in it. This demonstrates that the environment can be used, but in a sustainable way, thus generating environmental awareness in the pupils. Activities 4 and 5 serve to emphasize this fact.

Lastly, the category that relates Emotional Intelligence and Natural Heritage seeks, through emotions, to generate a bond of identity with the territory. It is worked on in Activities 2 and 6 . This bond, which should not be exclusive, emotionally fosters the pupils relationship with their environment, influencing their environmental awareness so as for them to want to preserve it, and therefore fostering the generation of future environmental citizenship.

In light of what has been analyzed, and taking together what has been observed, we believe that there is a close relationship between the approach of the program based on the informants thinking that we analyzed and their implementation of the activities. The sole intention was to attain the main objective of the Doñana, Biodiversity and Culture Program. As was detailed above, this is to create an identity bond between Donana and the pupils belonging to its environment. The idea is that they acquire a responsibility to perpetuating this territory in time and to its conservation by generating environmental citizenship for the present as children who inhabit the territory, and for the future as responsible citizens committed to the sustainable use of the territory.

\section{Discussion}

As can be seen in the analysis of the results, the proposal aims to achieve citizenship and environmental education of the students, that is, to form an environmental citizenship. The achievement of this objective supposes, as indicated by [6], a change in attitude that will entail a change in the behavior of citizens, with the intention of training critical citizens, with pro-environmental thoughts and with active participation in the path towards sustainability, that is, eco-literate citizens [46].

This need to train environmental citizens is generalized anywhere on the planet, as shown by authors such as [47], but even more so, in those territories of high ecological value such as the one at hand, the Doñana National Park, where the citizen has to live in balance with the system so that it can last over time.

Like [48], we think that creating social identity towards the environment and creating an environmental citizenship can be beneficial to instill prosocial behaviors, to become environmentally sensitive and responsible, generating a Territorial Intelligence in citizenship [49]. Therefore, the study participants are asked to visit an emblematic and protected place of the National Park, making them participate in a restricted territory and which they have accessed as citizens of the immediate environment, with the interest of generating positive emotions towards the himself and unique signs of identity. These signs of identity also favor their intrapersonal level and, the interpersonal, is developed through knowledge 
of the relationship that people who live in Doñana have and who make sustainable use of the territory. This, in addition, is linked to developing in them an environmental awareness, which as described by [50], allows them to develop feelings and respect, beyond the environment and in some way should allow a broader sustainable development with social and political implications, economic and cultural.

In short, generating practices of this type, which go beyond the pure preservation of the territory and which include the education of citizens from an environmental and sustainable point of view, can be a good way to ensure that future generations can enjoy the Planet that they find.

\section{Conclusions}

In view of the data and of the analysis carried out, it can be established that there is a close relationship between the thinking of those in charge of education in the protected area of Doñana and the proposed educational practices. Both are linked to educating and fostering the development of positive emotions towards the territory that determine a love for it, and to generating an identity bond, thus forging an environmental citizenship for the future. This issue coincides with the needs recently stated in the Congress held in Almonte (Huelva) dedicated to Doñana marking its 50th anniversary as a National Park. One of the conclusions most widely agreed upon was that " ... it is important to redouble the efforts of the environmental education, relationships, and communication of Donana with the surrounding populations".

However, and in order to not allow the creation of this identity bond in the population to deviate towards an exclusion of those who do not belong to the territory, it is necessary to constantly insist on and encourage tolerance, respect, and appreciation of diversity based on the knowledge of other territories. In this sense, there should be work on searching for links between territories. This is clearly expressed by [32] when referring to the responsibility of caring for humanity's nearby natural heritage because heritage is always global, also considering this to be a fundamental part of citizenship.

The program proposes education that is carried out from the sustainable use of the territory - its traditional uses and its enjoyment. The activities lend support to these issues at all times, taking advantage of the landmarks that appear in the landscape during the outing - hence, the need to foster creativity and to start speaking about education in sustainability rather than environmental education, as was also argued in the aforecited forum.

Sustainability Education focuses on students' abilities to embrace and develop a 'democratic action-competence', whereas Environmental Education is more product-oriented and oriented towards learning specific facts and attitudes [51]; however, some authors argue that, by integrating sustainability issues in a critical sense, Sustainability Education would better be replaced with Environmental and Sustainability Education [52].

What is certain is that there are authors like [53], who think that this approach may lead to forgetting the traditional approach to Environmental Education proposed in the Belgrade Charter, the part of ecological preservation. Jickling and Wals [54] argue that environmental education is being significantly altered by globalizing forces, witnessing the effort to convert environmental education into education for sustainable development. The ideal would be to achieve a balance between the two, since one, Education for Sustainable Development arises from the other, Environmental Education, by wanting to take into account aspects closer to human development. A balance between the two would entail reaching a preservation of nature without losing sight of human development in balance with it. Its basis should be the creation of a more holistic perspective on problems, which requires a deeper insight between the study of the environment and development problems [55]. In this study and, as a conclusion to the analysis of the Doñana, Biodiversity and Culture Program, this holistic treatment of the environment and the use that man makes of it is revealed, with the intention of achieving a balance in development.

With regard to the pupils' achieving emotional and territorial intelligence, both interand intra-personal levels were worked on. This fosters the relationship between the 
cognitive and the emotional in different interactions of landscape, citizenship, environment, and territory, always with the same objective of identifying the value of the territory and the pupils' proximity to an exceptional asset.

Finally, working with the territory from the perspective of Heritage Education, analyzing the natural, ethnic, and cultural heritage, in short, holistically, must achieve the knowledge and awareness of the value of a territory, creating identity and forming critical citizens who know to value what they have close by them, without any rivalry with other territories. In sum, it is a matter of the formation of critical citizens committed to their environment who are going to champion its preservation, with a well-developed environmental awareness and with the power to promote an increasingly committed environmental citizenship.

Author Contributions: All the authors contributed equally to this study. All the authors wrote, reviewed, and commented on the manuscript. All authors have read and agreed to the published version of the manuscript.

Funding: This study is linked to the R\&D + i project "Heritage education for the territorial and emotional intelligence of citizens. Analysis of good practices, design and intervention in compulsory education" (EDU2015-67953-P) which has made its preparation possible. The translation has been possible thanks to the funding of the Research Group "Marismas y Playas" (RNM 358).

Informed Consent Statement: Written informed consent has been obtained from the participants to publish this paper.

Acknowledgments: We thank the Doñana National Park Public Use Technicians Team and the Guide for their selfless collaboration, without which this study could not have been carried out.

Conflicts of Interest: The authors declare no conflict of interest.

\section{References}

1. UNESCO. Doñana National Park Marks 50 Years. 2020. Available online: https://whc.unesco.org/en/news/2086 (accessed on 27 January 2020).

2. Teixeira, S. Educación patrimonial: Alfabetización cultural para la ciudadanía. Estud. Pedagógicos (Valdivia) 2006, 32, $133-145$. [CrossRef]

3. Dobson, A. Environmental Citizenship and Pro-Environmental Behavior: Rapid Research and Evidence Review; Sustainable Development Research Network: London, UK, 2010.

4. Hadjichambis, C.; Reis, P. Introduction to the Conceptualisation of Environmental Citizenship for Twenty-First-Century Education. In Conceptualizing Environmental Citizenship for 21st Century Education; Springer: Cham, Switzerland, 2020.

5. Scholz, R.W. Environmental Literacy in Science and Society, from Knowledge to Decisions; Cambridge University Press: New York, NY, USA, 2011.

6. Dobson, A. Environmental Citizenship: Towards Sustainable Development. Sustain. Dev. 2007, 15, 276-285. [CrossRef]

7. Barry, J. Resistance is fertile: From environmental to sustainability citizenship. In Environmental Citizenship; Dobson, A., Bell, D., Eds.; MIT Press: Cambridge, MA, USA, 2006; pp. 21-48.

8. Kyza, E.A.; Georgiou, Y.; Hadjichambis, A.C.; Agesilaou, A. Antibiotics in livestock: Introducing in-service teachers to the nature of contemporary socio-scientific controversies. Sch. Sci. Rev. 2018, 100, 53-58.

9. Russ, A. (Ed.) Urban Environmental Education; Cornell University Civic Ecology Lab, NAAEE and EE Capacity: Ithaca, NY, USA; Washington, DC, USA, 2015.

10. Miranda, L. Cultura ambiental: Un estudio desde las dimensiones de valor, creencias, actitudes y comportamientos ambientales. Producción + Limpia 2013, 8, 94-105.

11. Smederevac-Lalic, M.; Finger, D.; Kovách, I.; Lenhardt, M.; Petrovic, J.; Djikanovic, V.; Conti, D.; Boeve-de Pauw, J. Knowledge and Environmental Citizenship. In Conceptualizing Environmental Citizenship for 21st Century Education; Springer: Cham, Switzerland, 2020.

12. Díaz Escobar, C. El enfoque del decrecimiento como estrategia de empoderamiento y transformación social. Un estudio de caso de los grupos de consumo agroecológico de Granada (España). Rev. Investig. Interv. Soc. 2014, 4, 49-71.

13. Assadourian, E. Educación ecosocial: Cómo educar frente a la crisis ecológica. In Educación Ecosocial; Icaria: Barcelona, Spain, 2017.

14. Misiaszek, G. Ecopedagogy and citizenship in the age of globalisation: Connections between environmental and global citizenship education to save the planet. Eur. J. Educ. 2015, 50, 280-292. [CrossRef]

15. Sverker, C.; Matti, S. Ecological Citizens: Identifying Values and Beliefs that Support Individual Environmental Responsibility among Swedes. Sustainability 2010, 2, 1055-1079. [CrossRef] 
16. Murga-Menoyo, M.; Novo, M. Sostenibilidad, desarrollo "glocal" y ciudadanía planetaria. Referentes de una pedagogía para el desarrollo sostenible. Teor. Educ. 2017, 29, 55-78. [CrossRef]

17. Espejel, A.; Flores, A. Educación ambiental escolar y comunitaria en el nivel medio superior, Puebla-Tlaxcala, México. Rev. Mex. Investig. Educ. 2012, 17, 1173-1199.

18. Alkaher, I.; Goldman, D. Characterizing the motives and environmental literacy of undergraduate and graduate students who elect environmental programs-A comparison between teaching-oriented and other students. Environ. Educ. Res. 2017, 24, 969-999. [CrossRef]

19. Boeve-de Pauw, J.; Van Petegem, P. Eco-school evaluation beyond labels: The impact of environmental policy, didactics and nature at school on student outcomes. Environ. Educ. Res. 2018, 24, 1250-1267. [CrossRef]

20. Kalogiannakis, M.; Papadakis, S. Combining mobile technologies in environmental education: A Greek case study. Int. J. Mob. Learn. Organ. 2017, 11, 108-130. [CrossRef]

21. Calaf, R. Un modelo de investigación en didáctica del patrimonio. Enseñanza Cienc. Soc. 2010, 9, 17-27.

22. Martín, M.; Cuenca, J.M. Educomunicación del patrimonio. Educatio Siglo XXI 2015, 33, 33-54. [CrossRef]

23. Fontal, O.; Ibáñez, A. La investigación en educación patrimonial. Evolución y estado actual a través del análisis de indicadores de alto impacto. Rev. Educ. 2017, 375, 184-214.

24. Fontal, O. La Educación Patrimonial: Del Patrimonio a las Personas; Trea: Gijón, Spain, 2013.

25. Cuenca, J.M. Análisis de las concepciones sobre la enseñanza del patrimonio en la educación obligatoria. Enseñ. Cienc. Soc. Rev. Investig. 2003, 2, 37-45.

26. Cuenca, J.M.; Martín, M. La comunicación del patrimonio desde propuestas de educación no formal e informal. In La Musealización del Patrimonio; González, J.M., Cuenca, J.M., Eds.; Universidad de Huelva: Huelva, Spain, 2009; pp. $35-46$.

27. González-Monfort, N. La educación patrimonial, una cuestión de futuro. Reflexiones sobre el valor del patrimonio para seguir avanzando hacia una ciudadanía crítica. El Futuro Del Pasado 2019, 10, 123-144. [CrossRef]

28. Novo, M. Educación ambiental y educación no formal: Dos realidades que se realimentan. Rev. Educ. 2005, 338, 145-165.

29. Martín, M.; Cuenca, J.M. La enseñanza y el aprendizaje del patrimonio en los museos: La perspectiva de los gestores. Rev. Psicodidáct. 2011, 6, 99-122.

30. Estepa, J. (Ed.) La Educación Patrimonial en la Escuela y el Museo: Investigación y Experiencias; Universidad de Huelva: Huelva, Spain, 2013.

31. Gómez-Redondo, C. Procesos de Patrimonialización en el Arte Contemporáneo: Diseño de un Artefacto Educativo Para la Identización. Ph.D. Thesis, Universidad de Valladolid, Valladolid, Spain, 2013.

32. Brusa, A. Paisaje y patrimonio, entre búsqueda, formación y ciudadanía. HerMus Herit. Mus. 2011, 7, 80-84.

33. Girardot, J. Inteligencia territorial y transición socio-ecológica. Rev. Asoc. Estatal Cent. Univ. Relac. Labor. Cienc. Trab. 2010, 23, 11-24. [CrossRef]

34. Trabajo, M.; Cuenca, J.M. La educación patrimonial para la adquisición de competencias emocionales y territoriales del alumnado de enseñanza secundaria. PULSO. Rev. Educ. 2017, 40, 159-174.

35. Goleman, D. Inteligencia Social: La Nueva Ciencia de las Relaciones Humanas; Kairós: Barcelona, Spain, 2008.

36. Sosa, M. Escala Autoinformada de Inteligencia Emocional (EAIE). Ph.D. Thesis, Complutense University, Madrid, Spain, 9 May 2008.

37. Zembylas, M. Emotional ecology: The intersection of emotional knowledge and pedagogical content knowledge in teaching. Teach. Teach. Educ. 2007, 23, 355-367. [CrossRef]

38. Mora, F. Neuroeducación. Solo se Puede Aprender Aquello Que se Ama; Alianza Editorial: Madrid, Spain, 2013.

39. Otero, M.R. Emociones, Sentimientos y Razonamiento en Didáctica de las Ciencias. Rev. Electrón. Investig. Cienc. 2006, 1, 24-53.

40. Bisquerra, R. (Coord.). Educación Emocional. Propuestas Para Educadores y Familias; Desclée de Brower: Bilbao, Spain, 2011.

41. Borghi, B. Educación patrimonial en Italia: Identidad y ciudadanía. In Identidad, Ciudadanía y Patrimonio. Educación Histórica Para el Siglo XXI; Molina, S., Llonch, N., Martínez, T., Eds.; Ediciones Trea: Gijón, Spain, 2016; pp. 39-62.

42. Pinto, H. Construcción de identidades y conciencia patrimonial: El papel de la educación patrimonial en Portugal. In Identidad, Ciudadanía y Patrimonio. Educación Histórica Para el Siglo XXI; Molina, S., Llonch, N., Martínez, T., Eds.; Ediciones Trea: Gijón, Spain, 2016; pp. 17-38.

43. Morín, E. Seven Complex Lessons in Education for the Future; Unesco Publishing: Paris, France, 1999.

44. Ibáñez, N. Las emociones en el aula. Estudios Pedagógicos (Valdivia) 2002, 28, 31-45.

45. Bisquerra, R. Metodología de la Investigación Educativa; Editorial La Muralla: Madrid, Spain, 2004; Volume 1.

46. Hartono, R. Evaluating Sustainable Education Using Eco-Literacy. Habitat 2020, 31, 78-85. [CrossRef]

47. Rockström, J.; Steffen, W.; Noone, K.; Persson, Å.; Chapin, F.S., III; Lambin, E.; Lenton, T.M.; Scheffer, M.; Folke, C.; Schellnhuber, H.J.; et al. Planetary boundaries: Exploring the safe operating space for humanity. Ecol. Soc. 2009, 14, 472-475. [CrossRef]

48. Lasrado, F.; Arora, B. Social identity and environmental citizenship in multinational corporations: An exploratory investigation and future research directions. Soc. Identities 2018, 24, 624-646. [CrossRef]

49. García-Madurga, M.A.; Grilló-Méndez, A.; Esteban-Navarro, M.A. Territorial Intelligence, a Collective Challenge for Sustainable Development: A Scoping Review. Soc. Sci. 2020, 9, 126. [CrossRef]

50. Fisman, L. The Effects of Local Learning on Environmental Awareness in Children: An Empirical Investigation. J. Environ. Educ. 2005, 36, 39-50. [CrossRef] 
51. Sund, P.; Gericke, N.; Bladh, G. Educational Content in Cross-Curricular ESE Teaching and A Model to Discern Teacher's Teaching Traditions. J. Educ. Sustain. Dev. 2020, 14, 78-97. [CrossRef]

52. Herranen, J.; Yavuzkaya, M.; Sjöström, J. Embedding Chemistry Education into Environmental and Sustainability Education: Development of a Didaktik Model Based on an Eco-Reflexive Approach. Sustainability 2021, 13, 1746. [CrossRef]

53. Kopnina, H. Education for sustainable development (ESD): The turn away from 'environment' in environmental education? Environ. Educ. Res. 2012, 18, 699-717. [CrossRef]

54. Jickling, B.; Wals, A. Globalization and environmental education: Looking beyond sustainable development. J. Curric. Stud. 2008, 40, 1-21. [CrossRef]

55. Tilbury, D. Environmental Education for Sustainability: Defining the new focus of environmental education in the 1990s. Environ. Educ. Res. 1995, 1, 195-212. [CrossRef] 